\title{
Political Marketing in the Lack of Political Market
}

\author{
Morteza Manshadi ${ }^{1}$ \\ ${ }^{1}$ Political Science Department, Ferdowsi University of Mashhad, Iran \\ Correspondence: Morteza Manshadi, Political Science Department, Ferdowsi University of Mashhad, Iran. \\ E-mail: manshadi@um.ac.ir
}

Received: June 19, 2017

doi:10.5539/jpl.v10n4p233
Accepted: July 19, 2017 Online Published: August 30, 2017

URL: https://doi.org/10.5539/jpl.v10n4p233

\begin{abstract}
Political marketing is an inter-disciplinary study. Goods which are produced in politics is a power. In marketing, power is presented in various classifications (promises) via politician signs (brand/mark) to political market. In a political market, the advertisement is considered as the basic element due to powerful controls dominating on public media is subjected to suspicion. As power realizing needs attention to internal funds of human experience, and individuals communicate through interchanging signs in harmful relationships, it is necessary to pay attention toward creation process and applying signs and meaning in every social relationship. The author believes that political marketing could result in a better choice merely in an abstract competitive market, while when there is no competitive market, marketing techniques makes a cheat on people. Therefore, how it is possible to prevent from tempting in a non-competitive market? The author believes that rival producers can prevent from marketing monopolized through focusing on the lifestyle of voters. This hypothesis will be tested in the realized sociology framework.
\end{abstract}

Keywords: political marketing, power, monopolization, meaning, realizing

\section{Political Marketing in the Lack of Political Market}

Statement of the problem: The American marketing association made the formal emergence of political marketing possible in 1985 by accepting "Ideal marketing" as a kind of marketing (Hussein Zadeh, 2012:27\&28). Afterwards political marketing has changed to a phase considered by marketing. Political marketing is an inter-disciplinary study and naturally, it is considered human science discoveries in branches concerned with marketing and politics to understand the meaning and application mood. Marketing has been established based on the system of the free market. The system of competition and free market faced with serious critics by sociologist scholars to the 1970s and 1980s. The dissolution of the Soviet Union and non-successful function of sociologist systems made the critical situation of sociologists weak. Antouni Gidenz as a modern democratic sociologist explains that socialism has got no other matter and socialist thought -revolutionary to reformistbelieves in pain and not reforming (Gidenz, 2008:105). It should be mentioned that these words should not be inferred as the end of history, but not well-formed structure and the defects of a competitive market should be considered.

If this county statement is accepted that human is per se the aim, a deep difference can be determined between approaches, and methods of human science with experimental science. Here, we do not aim to discuss on approaches and methods, only we refer to mentioned statement, individualism, and humanism considered human as an aimed and empowered existing. In this respect, the human is responsible to each freedom received. In politics, this responsibility is in law while in marketing, this responsibility is considered as proceeding to regard the principles.

The market got a heterogeneous structure, and makes try to obtain profit. Lindbloom believes that it's a blind market (Lindbloom, 2009: 44). Blindness refers to freedom in attaining positions in the market. This freedom is not an effect of competition, but is among reasons to form competition. Interventional and controlling politics are aimed by justice, investment and market positions. These interventions decrease the speed of the competition. Certainly, competition in a market is accomplished by intellectual and concentrated unit know themselves as omniscient with the aim of reforming and managing the market, while investors, entrepreneurs, and marketers make free market in a way to meet all demands of the clients (Von Mises: 708). It is supposed that actor selects the candidate among numerous candidates, and profit is in the same direction with free selection of actors in such 
a system.

It should be mentioned that there is a relation between freely selection with information circus and researchers' access to information. It is impossible to have access to total information in order to purchase or sale, but in conditions when total information is gathered, they are related to the past. Freedman (1988:11) asserts that information is formed in marketing system based on costs and only transmitted to the group in the need of information. The system of costs doesn't transmit information from final buyer to retailer, wholesaler, and the main producer, but perform in a reverse way. Finally, producers and users are dependent on each other in marketing system, and exchange with each other based on needs.

Undoubtedly, a structural bed rooted in the culture and customs of a society should be to keep mechanisms. In such a culture and customs, citizenship can be understood in a better way via interacting with marketing system, and democracy in politics is considered to be of freedom consequences in marketing (Gidenz, 1998:74). Therefore, political marketing is of high importance. So, how political marketing mechanisms perform? What are the similarities and differences of political marketing in developed and developing countries? The author applies an explanatory approach to answer questions and provides data by an understanding approach and historical-sociological method.

\section{Research Background}

There are too many literatures concerned with the subject of the study. Toofani Asl defined political cooperation in terms of democracy, sociology, and Islam and considered religious symbols, revolution symbols, open-minded symbols, advertisement-media tools, program tools, and party-political tools as six aspects of political marketing in Iran in his MA thesis (presented in 2007 in Tarbiat Modarres University) on "improving political cooperation with Iranian citizens: The determination of political marketing (The opinions of political authorities). He reached to a conclusion that applying six tools of political marketing in Iran (program tools, political tools, revolution symbols, advertisement-media tools, religious symbols, and open-minded symbols; respectively) result in improving political cooperation among citizens. He didn`t consider political marketing with the same view of the present study and has just focused on Iran. Also, Muhammad Hussein Zadeh had a different look on this matter with a focus on Iran in his MA thesis on "The role of political-news websites on succeeding in the political market in Iran" (presented at 2012 in Ferdowsi University of Mashhad). In addition, the emphasis on the sufficiency of political marketing has made these studies different from the present one. Bahram Kheiri and Mansoureh Abbass Ali Zadeh explained the sufficiency of marketing techniques in politics in an article on "Political marketing; proceeding to market-oriented political organizations" published in "Modiriyat-e-farhang-e sazemani Journal, No. 18, 6th year, autumn and winter of 2008. On the effect of political marketing on voters with emphasis on the election in 1992 in England, Hiss and Mc Elister (1996) believed that floating voters have the least information on politics and participation in elections. Therefore, it is the smallest group which was convinced through political marketing. They suggest political parties to apply marketing techniques just before the election and they are the target voters who make a decision in a year or two years before election. Pistoulas (2008) made an attempt to consider the effect of political marketing on the behavior of Greek voters to find the role of political marketing in making decision to vote especial candidates in various parts of candidate fields. He concluded that the voters of whole candidate fields are aware of the high impact of political marketing, but they refuse to accept that they are influenced. It seems that only voting and TV advertisements got different effects. All these studies have no inter-discipline view and have looked at marketing in politics with an especial view and an aim to prove the abilities of marketing in politics. The present study makes an attempt to consider the sufficiency of political marketing in developing countries by applying sociology, economics, political science, and management. Nowadays, all countries are dependent on each other, but different conditions in different fields make researchers be cautious in applying world-containing views.

\section{Theoretical Framework}

In the societies in which democracy has been accepted as a political lifestyle, elections are considered as the most familiar method to select political managers. In this way, competition is considered among candidates of the highest political candidates as the most passionate aspect of political life to them. In political science, considering the voters ' behavior and the method of political selection was a research unit. Experience-oriented and intellectual selection approach were the most applied research methods to determine the political behavior of people selected. Behavior-oriented researches know having access to the causative pattern of political behavior as the main purpose, and determine variants such as literacy, gender, class, and rate with political choice as matters occupied the behaviorists ' mind. It should be mentioned that behaviorists try to consider purpose with no explanation in political science and economics (Manouchehri, 2008:46). Anyway, political behavior is 
considered just like political activities in this approach, and therefore political marketing can be mentioned. Political marketing turns to be business world based on the sellers (candidate nominates), goods and services (advertisements), and approach (obtaining the votes).

On the other hand, there are numerous views in political science focusing on human purposes in social activities. In this view, a partial understanding of social reaction is seen without focusing on the definition of social situations by researchers, and their functions will be vaguely based on the definition. It means that individuals are not only inactive accepters, but they get into the social life actively and make social and political phenomena active. In this view, the relationship between individual awareness and political marketing is established based on knowledge set in access to researchers, and the researcher got awareness through these social patterns. In this respect, meaning and motivation in social action should be differentiated from each other.

Conducted action has been predesigned based on a pattern. The significance of action is as a result of this pattern. When this pattern considers another action, it turns into a social action (and vice versa). Action should test and select different patterns, and when patterns are not applied in determined situations to achieve practical purposes, they should be selected. Intellectual significance is created through independent identifying the reality, and the action supposes some elements of reality to be meaningful. Those meanings existed in all cultures are considered as the property of all actors. As these meanings are objective and non-individual, they can be considered.

In fact, motivation is the actor's reasons to establish an action. Usually, sociologists differentiate two types of motivation. One motivation is called as "until that". These motivations are the actor's reasons to establish action which have been created to fulfill an event in the future. The other motivation is named "wherefore". These motivations are reasons which make individuals to behave in especial way. By passing time, these actions are formed and are studied by scholars (Ritzer, 1995:350-351).

As individuals got an awareness and thought, and are influenced by cultural necessities simultaneously, the matter should be maintained. At the individual level, actors make a social reality through awareness and thoughtfulness, they form activities, and therefore they are free in acting. While, society culture is added to activity, it seems that actor has to consider the values and norms of society, and should be controlled by them. In this respect, it is complicated and discord to understand individual's understanding. In this study, the author makes an attempt to explain social and political activity and doesn't consider these problems. He believes that it is possible to solve some vague by self-understanding, although intellectually it is difficult to consider these self-understandings in an experimental way.

\section{Political Marketing/The Lack of Political Market}

Considering the variety of political systems of the country is considered as the first and most important matter on politics in developing countries. There are different types of political systems in developing countries included inherited the kingdom to parliamentary republics, elitist systems based on tribe and eldership to revolution systems and democratic-based systems based on public organization, and totalitarian dictatorships to multi-totalitarian democracies (Saei, 2000: 250). The maintenance of old accusation of plot and intriguing by enemies (in most cases they are imaginational intriguing) can be a common aspect in all systems between the public and government.

Many scholars believed that in developing countries, there was a fierce quarrel among advertisement, field, tribe, or religious groups to 1980s, so that it was impossible to attain a harmony on political principles. Each group prefers principles to keep benefits, and to make other group benefits limited or to decrease (Bernal \& Rendal, 2008:179). Based on the conclusions, Harrison asserts that "in most developing countries, there is no stable opinion on transmitting power. Groups with no power apply violence when they realize that benefits are not attained via discipline in the society (Harrison, 2008:465). In fact, there is much violence in developing countries so that tempts spectators to consider violence as a part of political life.

In developing countries, corruption and weakness of economical and social classes not supporting changes and excessive intervention of the government in affairs have resulted in failure. Up to 1980s, only a few numbers of developing governments were as consolidated democracies or at least as electable democracies (Bernal \& Rendal, 2008:178-179). Scholars believe that there is impossible to establish pluralistic democratic systems as the result of lacking in the national system, low grade of economical development, outer pressures, cultural background, and historical experiences (Saei, 2000: 257-258).

In political marketing, the political parties play the role of producers in economy. Intellectually, there is no doubt that there is no relationship between the growth of political parties and forming political systems based on party competitions with a civilian society. However, there are not initial principles and preconditions of consolidating 
the political parties in developing countries (Saei, 2000:263).

In modern and powerful governments, it is impossible to have an efficient and powerful government with no powerful economics. On the other hand, powerful economies can't be formed without the help of governments. In a more exact way, development based on the market is not successful without the supporting of government in investing on humans and society. Certainly, market is the necessary but not enough condition for democracy. Beetham believes that although market and politics strengthens each other, and when one of them is assured in law, the other will be assured too, and both of them are in contrast with patriarchy, market disciplines make the unification of democracy weak, and individuals prefer to exploit the public field (Beetham, 1997: 76-93).

There is a different condition in developing countries. In other words, the government is active in the lack of market in developing countries. The unsound cooperation between economical and political power results in obtaining political positions. All facilities are in the hands of the government. In many developing countries, votes can be bought and sold. Votes are attained through money or job suggestions. The people of these countries know election as a ceremonial affair with no effect on life. It is legal to sale votes in developing countries as it's a useless matter. Although selling votes is accomplished in secret, sellers do a favor to buyers (Harrison, 2008:449-450). Therefore, democracy is considered as a ceremonial matter in developing countries which can't be afforded by these countries. The experience of business tigers in western Asia makes emphasis on the profit of wealth theory democracy on precedence while, India as the most developing democratic country with per capita income of $2000 \$$ and a population with less that 1-dollar income in each day violates the theory (Bernal \& Rendal, 2008:219).

In developing countries, it is common that there is the lack of independency and dependency of institutes and official and economical departments to each other. In fact, clientalism and neopatrimunial patterns decrease the significance of function based on the program and support votes in a way desired to supporter. Officiate is of importance in developing countries. Traditional methods of face-to-face are maintained between candidates, and loyalty to family is of more significance in comparison to loyalty to the government. Clientalism got three properties: "The connection between supporter and follower between two groups with no equality in situation, power, and wealth. Second, the formation and continuation of this relationship depend on mutual deals. Third, the expansion and survival of this system depend on face-to-face communication between supporters and followers (Saei, 1996:224). Clientalism systems act on two levels. At the lowest level, followers are gathered in countries and slums through a big connection between individuals and powerful supporter supporting the benefits of followers and gets respect. In a higher level, the follower is among the national elite. Here, the supporter forms a communication with elite to show loyalty toward the system and services' elite in marches and in elections (Saei, 1996: 225).

The lack of independence of institutes makes corruption broad. The applying of financial support of economical producers in election advertisements with authorization by politicians results in abuse. Therefore, dirty money is discussed here. In the lack of market in developing countries, monarchy and republic are permanently sometimes, and political positions are considered as absolute properties of authorities. Here, I applied corruption in the meaning of applying governmental facilities for personal benefits.

Great corruption is figured as a property of the lack of political market in developing countries (Harrison, 2008:438-442). In the lack of political market in developing countries, money results in power, and the power of money has connected great corruption, political and economical power to each other, and makes the government weak and unstable. Great corruption ruins the trust between the public and government, and makes power and government legitimacy weak. In this way, it disrupts social discipline in a society.

Human activities are accomplished based on the individual's information and awareness. The public media and the press are the greatest sources of obtaining information. According to statistics, in most developing countries, there is an official news agency and at least a communicating tool under the control of government to make assure that people become aware of matters considered by the government. In all cases, censorship is accomplished to prevent from critics on government decisions and policies (Saei, 1996:160).

Political marketing signifies in election periods. In many developing countries, not only voting is encouraged, but it forces people to vote. As a general principle, almost one-third to half population of citizens enroll to vote, among them $75-90 \%$ of people vote, and om average $70.04 \%$ of voters have been in developing countries (Gastil, 1982:25-29). In most developing countries, the results of election are not trustable due to the procedure of power dominating in the society, as disagreed parties are suppressed, illiterate rural people and urban workers are forced to vote to dominated powers, invaders oppress the political parties, and disturb the candidate staffs, vote boxes are lost or announced to be disturbed, there is no free and equal chance to all election candidates, and in 
some cases just one candidate is present, and finally the election is declared to be false as a result of rival's victory in the election (Taylor, Hudson, 1972: 57-58).

Considering what has been discussed, there is a monopolized political market in developing countries, and there is the least opportunity for rivals and free choice among various items. Therefore, the term "lack of market" is a more suitable term to the politics of these countries. In the lack of market, political marketing is an insufficient tool to increase competition and a suitable technique to empower monopolization, and extends the gap between people and government in a greater extent.

\section{Conclusion}

Political marketing signifies in competitive markets. Equal opportunity, facilities and access to information in a similar way are considered as properties of such markets. The independent of civilian society and structural separation determine the specific activities of institutes, social and political organizations. Cooperation in public arenas in such space accompanies with competition. There is a different condition in developing countries. In these countries, political monopolization makes public domain to a limited scope in which there is a close circus among the elite. The relationship between these elites and public mass is established through a system supporting follower. In this respect and in the best mood, political cooperation is established in an initial way, and political competition is of no significance. In developing countries, parties don't react to peoples' needs while they answer to the government needs as a result of lack in political parties and organized beneficiary groups, it means that parties take the government needs to people, therefore the government makes decisions so that differentiation of power is discarded to accelerate activity and to prevent disagreement. In these countries, the government believes that it hears people voice and asks people to accept media statements as their own needs. In such a condition, applying marketing techniques and knowledge results in making political space closer and taking away people (users) from the realities. Political marketing in the lack of marketing in developing countries makes conditions to be more unstable by emphasizing on the un-trusted gap between people and government. The actors` activities are signified by meaning formed in their brains. Here, there is no obligation and people are free to react toward information received. When power space and resources of obtaining formal news control are monopolized, some reactions are formed such as getting news from informal resources as the most familiar result. Rumors are expanded and accepted in high speed. In such a condition, it seems that political marketing techniques turn to be powerful tools of the governor, and it is in contrast with the competitive purposes of the market.

\section{References}

Beetham, D. (1997). Market Economy and Democratic Polity. Democratisation, https://doi.org/10.1080/13510349708403503

Bernal, P., \& Rendal, W. (2008). The problems of third world. Tehran, Qoms publication.

Freedman, M. (1988). Freedom of selection. translated by Hussein Hakim Zadeh Jahroomi, Tehran, Parsi publication.

Gastil, R. (1982). Freedom in the World. Westport, CN: Greenwood. Gatrell.

Gidnz, A. (1998). Third way. translated by Manouchehr Saboori, Tehran, Shirazeh publication.

Gidnz, A. (2008). The left and right far side. translated by Mohsen Salasi, Tehran, Elmi publication.

Harrison, P. (2008). Inside of third world. translated and published in Tehran.

Hussein Zadeh, M. (2012). The role of political-news websites on the situation of political marketing in Iran. MA thesis, Ferdowsi University of Mashhad, Political and official faculty.

Kheiri, B., \& Abbas-Ali Zadeh, M. (2008). Political marketing, proceeding to market-oriented political organizations. The management of organizational culture, 6(18).

Lindbloom, C. (2009). The system of market. translated by Muhammad Maljoo, Tehran, Ney publication.

Manouchehri, A. (2008). Approach and method in political science. Tehran, Samt publication.

Ritzer, G. (1995). The sociological theory in contemporary time. translated by Mohsen Salasi, second edition, Tehran, Scientific publication.

Saei, A. (1996). An introduction on political-economical problems of third world (2nd ed.). Tehran, Qoms publication.

Saei, A. (2000). The political-economical problems of third world (3rd ed.). Tehran, Samt publication. 
Taylor, C. L., \& Hudson, M. C. (1972). World Handbook of Political and Social Indicators. New Haven, CT: Yale University Press.

Toofani Asl, E. (2007). The improving of political cooperation of Iranian citizens; the determination of political marketing. MA thesis, Tarbiat Modarres University, Human science faculty.

Von Mises, L. (1963). Human Action: A Treatise on Economics (3rd ed.). Henry Regnery Press, Chicago.

\section{Copyrights}

Copyright for this article is retained by the author(s), with first publication rights granted to the journal.

This is an open-access article distributed under the terms and conditions of the Creative Commons Attribution license (http://creativecommons.org/licenses/by/4.0/). 